\title{
FEDERAL EXPERIENCE WITH CONSUMPTION EXCISES
}

\author{
Charles R. Kavanaugh*
}

It is not surprising, in view of the complexity of the federal income tax laws and the extent of their application, that the excise taxes are completely overshadowed by the income taxes in the minds of many tax students and practitioners. Nevertheless, the tendency on the part of some of them to dismiss excise taxes as temporary expedients is clearly unwarranted. Such taxes, in varying forms, are undoubtedly here to stay and therefore deserve closer attention than is ordinarily accorded them. This is particularly true at the present time, as it may well be that these taxes will be extended to cover an ever widening circle.

Both historically and fiscally, excise taxes have played an important part in the federal tax system. The experience of the Government with these taxes began 150 years ago and falls within three distinct periods- $779 \mathrm{I}$ to $1802,{ }^{1} \mathrm{I} 8 \mathrm{I} 3$ to $I 8 \mathrm{I} 8,{ }^{2}$ and I862 to the present time. ${ }^{3}$ The taxes on liquor and tobacco constituted the backbone of our modern system of taxation at its inception in $1862,{ }^{4}$ and for many years thereafter these taxes continued to be the principal sources of internal revenue. ${ }^{5}$ The internal revenue receipts for the first two periods referred to above were $\$ 6,758,764.26$ and $\$ 25,833,449 \cdot 43$, respectively. ${ }^{6}$ In contrast to these relatively modest amounts, total tax collections for the fiscal year $194^{\circ}$ were in round figures 5 billion dollars. ${ }^{7}$ The excise taxes produced approximately three-fifths of this sum, while the income taxes accounted for the balance. ${ }^{8}$

A.B., I928, LL.B., 193I, Stanford University. Member of the California Bar. Attorney, Chief Counsel's Office, United States Bureau of Internal Revenue.

Although the writer is employed by the United States Bureau of Internal Revenue, the views expressed herein are entirely his own and nothing herein shall be taken as the official opinion of the Bureau of Internal Revenue.

1 The taxies of the first period were imposed with respect to carriages, retail dealers in wines and foreign spirituous liquors, snuff, refined sugar, property sold at auction, legal instruments, real estate, and sales. Codification of Internal Revenue Laws (1938) xi.

2 The subjects of the taxes of the second period were refined sugar, carriages, distillers, sales at auction, distilled spirits, manufactured articles, household furniture, watches, gold, silver, plated ware, jewelry, real estate, and slaves. Ibid.

3 The Act of July $x$, I862, which marked the beginning of the third period, created the office of Commissioner of Internal Revenue and "taxed practically everything which Congress thought was susceptible of yielding revenue." Ibid. Ibid.

'Even in the fiscal year 1940, liquor and tobacco taxes produced more than one-fifth of the total revenue. Rep. CoM'R INT. Rev. (I940) I, 2.

${ }^{\circ}$ Codification of Internal Revente Laws (1938) xi.

${ }^{7}$ Rep. Com'r INt. Rev. (I940) I, 2. ${ }^{8}$ Ibid. 
The purpose of this paper is to discuss important phases of the Government's experience with such of the present excise taxes as may be classified as consumption excises. Admittedly, the classification of excise taxes into consumption excises and others is open to the objection that it is somewhat unrealistic, as government officials do not, in the practical work of administering the excise tax laws, think or talk in such terms. Nevertheless, it would seem that taxes which are measured by prices or quantities and paid by consumers or passed on to them may properly be classified as consumption excises.

\section{Admissions}

The several admission taxes, ${ }^{0}$ collected ${ }^{10}$ from the patrons and paid over ${ }^{11}$ to the collector, are component parts of a comprehensive system designed to cover admissions as a whole. ${ }^{12}$

\section{Admissions to Any Place}

The admission tax which has the widest application is of course the one ${ }^{13}$ with respect to admissions to any place. Strangely enough, the nature of the transactions to which this tax applies would seem to vary with the circumstances. In the usual case where the amount paid exceeds the taxable minimum, the transaction is the act of paying for the admission ${ }^{14}$ rather than the exercising of the privilege to enter, for the tax is payable regardless of whether such privilege is ever exercised. ${ }^{15}$ In the case of a taxable free or reduced-rate admission, ${ }^{16}$ the nature of the transaction to which the tax applies is not spelled out clearly in either the statute or the regulations. If the right to such admission is evidenced by a ticket, the tax is payable upon the issuance of the ticket. ${ }^{17}$ This requirement indicates that the taxable transaction is the act of receiving the ticket or, in the case of a reduced-rate admission, probably the payment for the ticket. On the other hand, if the right to such admission is not evidenced by a ticket, the tax is payable upon admittance. ${ }^{18}$ The implication of this requirement is that, in the case of a free admission, the transaction is the actual exercise of the privilege to enter the place and that, in the case of a reduced-rate admission, the transaction is either the same as in the other case or is the payment for the admission, the payment of the tax being postponed until actual admittance if the admission payment preceded that event.

The meaning of the term "place," as used in the statute ${ }^{10}$ imposing the general admission tax, has been the subject of some controversy. The regulations ${ }^{20}$ provide that the basic idea conveyed by this term is that of a definite inclosure or location, and that places of amusement obviously constitute the most important class of

${ }^{9}$ INT. REv. CODE $\$$ I700.

${ }^{10}$ Id. \$1715(a). ${ }^{11} I d$. $\$ 1715(b)$.

12 Excluded from the present study, because not within the field of consumption excises as defined, are the taxes on sales of tickets at excessive prices.

${ }^{13}$ INT. REV. CODE $\$$ İOo(a)( $(x)$.

${ }^{25}$ Ibid.

${ }^{17}$ U. S. Treas. Reg. 43 (1940) \$ror.5.

${ }^{10}$ Cited supra note 13 .

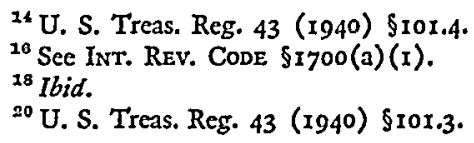


"places." It includes, in addition to ordinary places of amusement, a swimming pool, ${ }^{21}$ a skating rink,, 22 and a private mountain resort, ${ }^{23}$ but it does not include a sight-seeing aircraft. ${ }^{24}$ Another ground for contesting the application of this tax has been that the charge in question was not for admission but rather for rent, expenses, or other purposes. A charge required for admittance to a swimming pool ${ }^{25}$ or skating rink ${ }^{26}$ is an admission charge, even though payment entitles the persons to the use of a swimming suit and towels or skates. The same rule applies where a so-called toll charge ${ }^{27}$ is collected on a private road leading to a mountain resort, and in the case of a so-called contribution ${ }^{28}$ paid for a ticket entitling the "contributor" to a seat at a political mass meeting. But a charge for transporting guests to and from an island on which is maintained a private beach is apparently for transportation expenses and is not an admission charge. ${ }^{29}$ Nor is the amount which a student is required to pay, as a student activity fee, for a non-transferable book good for admission to student activities and athletic events. ${ }^{30}$ However, if the payment by the student is voluntary, as in the case of student season tickets, it is held to be an amount paid for admission. ${ }^{31}$

This tax, as applicable to admissions to dances, may not be avoided by the expedient of a multiple or combination ticket. In such a case, the admission charge is the total amount paid for the entire ticket.32 Several questions have also arisen concerning application of the provisions as to taxable free or reduced-rate admissions. $^{33}$ The statutory exception as to persons who may be admitted free without payment of tax does not include children over $\mathrm{x} 2$ because of the fact they are inmates of charitable institutions, nor members of the Civilian Conservation Corps, nor men in the Army, Navy, or Marine Corps. ${ }^{34}$ It has also been urged that where ladies are admitted to a ball game without charge or at reduced rates, no tax should be required, the theory being that the basis on which they are admitted constitutes the established price for the accommodations to which they are restricted. But as their seat accommodations are substantially similar to those in other parts of the stands for which regular admission price is charged and as the privilege is confined to women and limited to one day a week, the Bureau's position is that their admission is taxable under the statute. ${ }^{85}$

The taxability of public admissions to athletic events held by state schools was not definitely settled until recently. The application of the tax to such admissions was vigorously contested on the ground that the tax unconstitutionally burdened the

\footnotetext{
${ }^{21}$ T'win Falls Natatorium v. U. S., 22 F. (2d) 308 (D. Idaho I927); S. T. 859 , I937-I C. B. 334.

${ }^{22}$ U. S. v. Koller et al., 287 Fed. 418 (W. D. Wash. 1921), appeal dismissed, 260 U. S. 757 (1922).

${ }^{23}$ Chimney Rock Co. v. U. S., 63 Ct. Cl. 660 (1927), cert. denied, 275 U. S. 552 (1927).

${ }^{34}$ S. T. $66_{4}$, XII-I C. B. 424 (1932).

25 Twin Falls Natatorium v. U. S., supra note 2I. $\quad{ }^{26}$ U. S. v. Koller et al., supra note 22.

${ }^{27}$ Chimney Rock Co. v. U. S., supra note 23. $\quad{ }^{28}$ S. M. 2853 , TV-I C. B. 294 (1924).

${ }^{20}$ Huguenot Yacht Club v. U. S., 32 F. Supp. 387 (S. D. N. Y. 1940).

${ }^{30}$ S. T. 563, XI-2 C. B. 522 (I93I). ${ }^{31}$ Ibid.

${ }^{32}$ S. T. 670, XII-I C. B. 423 (I932). $\quad{ }^{33}$ INT. REV. CODE $\$$ I700(a)(I).

at S. T. 910 , 1940-2 C. B. 315. Cf. U. S. Treas. Reg. 43 (1940) §10r.5, excepting reporters, photographers, telegraphers, and radio announcers whose special duties are the sole reason for their ${ }^{35}$ S. T. 697, XII-2 C. B. 353 (1932).
} presence. 
states in the exercise of their governmental functions. The Supreme Court set this problem at rest by holding ${ }^{36}$ that such admissions are properly taxable, saying that "the conduct of exhibitions for admissions paid by the public is not such a function of state government as to be free from the burden of a non-discriminatory tax laid on all admissions to public exhibitions for which an admission fee is charged." Similarly, admission charges to a swimming pool operated by a city or other municipality are taxable. ${ }^{37}$

\section{Use or Lease of Boxes or Seats}

The nature of the transaction embraced by the $\operatorname{tax}^{38}$ relating to boxes and seats in an opera house or place of amusement is not clear, and apparently there are no rulings or decisions on this point. As the tax applies regardless of whether the box or seat is used or whether any amount was paid therefor, ${ }^{30}$ it would seem that the tax is imposed with respect to a person's having the permanent use of or a lease for the use of the accommodation. ${ }^{40}$ The major difficulty encountered in administering the law imposing this tax lies in computing the amount of the tax in certain instances. The tax is based not on the amount, if any, actually paid for the box or seat, but on the amount that would be paid, at the established price, for admission to all performances given, not merely those attended, if payments were separately made for each performance. ${ }^{41}$ If there is no comparable box for the use of which on single occasions admission charges are made, the tax is computed by determining the amount for which a single box seat in the same part of the house is sold, multiplying that amount by the number of seats in the box, and calculating the tax on the basis above indicated. ${ }^{42}$ If there is no box located in a similar position, the tax is computed by determining the amount for which a single seat in the same part of the house is sold, multiplying that amount by the number of seats in the box, and calculating the tax accordingly. ${ }^{43}$

\section{Admissions to Cabarets}

The specific transaction to which the cabaret tax ${ }^{44}$ applies is not clear. Although, in a broad sense, the transaction contemplated by the statute is the exercise of the privilege to avail oneself of the entertainment, refreshment, and food furnished at the cabaret, it would appear that technically the taxable transaction is the act of paying the amount that includes the admission charge; for both the statute ${ }^{45}$ and the regulations ${ }^{46}$ provide that the tax applies to the payment of such amount.

Difficulties have been experienced in applying this tax to hotels providing orchestra music and dancing facilities for their patrons in connection with their dining rooms. The regulations ${ }^{47}$ state that the entertainment furnished in such a case is a public

\footnotetext{
${ }^{36}$ Allen v. Regents of the University System of Georgia, 304 U. S. 439 (1938).

${ }^{37}$ S. T. 907 , I940-2 C. B. 316 . ${ }^{88}$ INT. REV. CODE $\$ 1700(b)(1)$.

${ }^{30}$ U. S. Treas. Reg. 43 (I940) $\$ 101.8$.

«U. S. Treas. Reg. 43 (I940) \$Ior.8.

${ }^{3}$ Ibid.

4 Ibid.

"Id. \$roI.I4.

${ }^{\circ 0} \mathrm{Cf}$. INT. Rev. CODE $\$(1410,1520$, and $x 600$.

12 Ibid.

«INT. Rev. CODE $\S I$ IOo(e)(I).

${ }^{40} U$. S. Treas. Reg. 43 (1940) \$101.13.
} 
performance for profit and that, if no admission charge for the dance is separately made, the amount paid for refreshments shall be deemed to include the admission charge. In a recent case, ${ }^{48}$ the orchestra and dance floor were in one dining room, but patrons of other dining rooms of the hotel were permitted to use the dance floor. There was no cover, minimum, or other special charge. The court held that, though the performance was public, it was not for profit, that no part of the amount paid for refreshments was an admission charge, and that accordingly the hotel was not subject to the tax. The court distinguished the entertainment in this case from entertainment for profit by saying that here it was actually an item of general hotel overhead.

A minimum charge, ${ }^{49}$ entitling the patron without further payment to the food and refreshments totaling that amount, is not an amount paid for admission within the meaning of the statute imposing the general admission tax. ${ }^{50}$ If the minimum charge is exceeded, it is included as part of the total bill on which the cabaret tax is based. ${ }^{51}$ On the other hand, a so-called cover charge is taxable as an amount paid for admission under the general admission statute. ${ }^{52}$ If such a charge is inadequate to cover the cost of the entertainment provided, part of the charge for refreshment is deemed to be for admission and subject to the cabaret tax.53 The determination of the adequacy of the cover charges involves an examination of the daily food and refreshment checks and a comparison of the receipts from cover charges with the cost of the entertainment. This determination is frequently hard to make, particularly where the records of the cabaret proprietor are incomplete. In order to avoid the application of two separate admission taxes in the case of cabarets making cover charges and to eliminate the complications that are often involved in determining the cabaret tax, it would seem that the admission tax laws should be so amended that the general tax would not apply to cover charges and that the cabaret tax would be a fixed percentage applicable to the total cabaret bill.

\section{Exemptions}

Admissions for the benefit of certain organizations and persons are exempt from the admission taxes, if the varying conditions specified in the statute ${ }^{54}$ are fulfilled. Even though the purposes of an organization, as set forth in its by-laws, are charitable, it will be denied exemption if any of the funds raised through admissions are used for noncharitable activities. ${ }^{55}$ Similarly, an organization which engages in educational and non-educational activities is not entitled to exemption as an educational organization..$^{56}$ The exemptions as to persons have occasioned some difficulty. Originally it was held that the exemption relating to firemen applied only if the proceeds of the admissions inured to the benefit of the firemen of a city as a class. ${ }^{57}$ The present position of the Bureau, however, is that the exemption applies whether the proceeds inure to the benefit of the class or of a single individual. ${ }^{58} \mathrm{~A}$ condition

\footnotetext{
${ }^{4}$ The Deshler Hotel Co. v. Busey, 36 F. Supp. 392 (S. D. Ohio I94x).

${ }^{10}$ S. T. 799, XIV-I C. B. 420 (I934).

${ }^{10}$ See INT. REv. CODE $\$$ I700(a)(I).

${ }^{\mathrm{ca}}$ U. S. Treas. Reg. 43 (I940) §ror.13.

IINT. REv. CODE \$I701.

${ }^{\pi 0}$ S. T. 885 , 1939-2 C. B. 37 I.

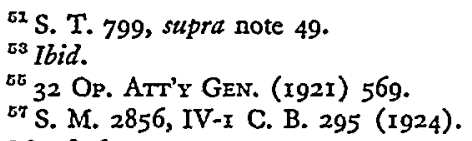


to the application of the exemption as to agricultural fairs is that no part of the net earnings of the fair shall inure to the benefit of any stockholder of the fair association. ${ }^{59}$ Net earnings are those arising from the operation of the fair itself. ${ }^{00}$ If the association has stock outstanding upon which dividends may be paid when receipts from the fair warrant such distribution, exemption will be denied. ${ }^{61}$ It is immaterial that the fair revenues for a particular year or series of years are devoted exclusively to the improvement of fair property ${ }^{62}$ But if the only earnings distributable are those from sources other than the operation of the fair, the association will not be barred from the exemption. ${ }^{63}$ There is no exemption broad enough to cover theatrical performances sponsored by the Works Progress Administration, ${ }^{04}$ nor a club organized to continue the associations formed at a citizens' military training camp and to promote the success of the camp in succeeding years. ${ }^{65}$ Curiously enough, part of the amount paid for a given lot of admission tickets may be taxable and part nontaxable. Thus where a charitable organization bought tickets from a theater and sold them at a price in excess of the established price plus tax, the amounts paid to the theater were ruled taxable, whereas the excessive charges made by the charitable organization were not. ${ }^{86}$

\section{Evasion and Avoidance}

Field audits or investigations have uncovered various methods to evade or avoid the admission taxes, though there seem to be no serious attempts at evasion in the case of the tax relating to boxes or seats in opera houses or places of amusement. A common method of evasion is failure to keep any records or the keeping of false records. Again, the collecting agent may fail to collect or pay over the tax, or, in the case of the general admission tax, he may try to muddy the waters by filing a fraudulent or erroneous claim for exemption. In a few instances resort has been had to collusive contracts in order to obtain the benefits of exemption. A dishonest officer of an exempt organization may enter into such a contract with a promoter, the contract providing that the proceeds of admissions will inure to the organization, but the secret understanding being that part at least of the proceeds will go to the promoter. As there is a minimum taxable admission in connection with the general admission tax, such tax may be avoided altogether by reducing the admission price below that figure. Similarly, a method of evading the cabaret tax involves the proration of the total bill for a party of a number of persons among such persons, in order that the prorated charges will be below the taxable amount.

\section{Dues and Fees}

The taxes ${ }^{67}$ relating to dues and fees paid to a social, athletic, or sporting club or organization and life memberships in such a club or organization are paid ${ }^{08}$ by the members to the club and paid over ${ }^{69}$ by the club to the collector.

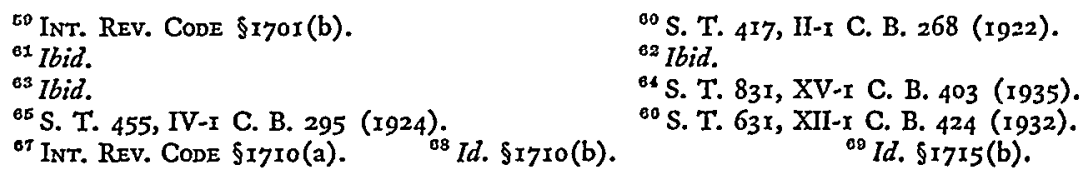




\section{Dues}

In view of a recent ruling ${ }^{70}$ that the higher rates which went into effect on July I, I940, apply to dues payments made on or after that date, regardless of when the period covered by the dues began or ended, the transaction to which the dues $\operatorname{tax}^{\mathbf{7 1}}$ applies would seem to be the payment of the dues. Broadly speaking, however, this tax is imposed in respect of a person's possession of the right to enjoy the privileges and facilities of the club or organization.

The determination of whether a particular club is a social one within the meaning of the statute presents one of the major problems in the administration of the dues tax statute. The tests ${ }^{\mathbf{7 2}}$ which have been worked out administratively are simple; it is the application of them that is difficult. If the social features are a material purpose of the club, it is a social club. On the other hand, if the social features are not a material purpose of the club, but are subordinate and merely incidental to the active furtherance of a different and predominant purpose, such as religion, the arts, education or business, it is not a social club. While the courts have not found fault with these administrative tests, they have experienced similar difficulty in applying them. Recent cases involving the application of these tests are listed in the margin. ${ }^{73}$

A club for the practice or promotion of athletics or sports is an athletic or sporting

${ }^{70}$ S. T. 904, 1940-2 C. B. 320.

${ }^{71}$ INT. REV. CODE $\S I 7 X 0(a)(\mathrm{I})$.

${ }^{72}$ U. S. Treas. Reg. 43 (1940) §101.38.

${ }^{73}$ Clubs held social: Duquesne Club v. U. S., 23 F. Supp. $78 \mathrm{x}$ (Ct. CI. I938), cert. denied, $306 \mathrm{U}$. S. 649 (1939); Denniston v. U. S., 23 F. Supp. 305 (S. D. Ala. I938); Union Club of Hoboken v. U. S., 22 F. Supp. $4^{16}$ (Ct. Cl. 1938); Detroit Club v. U. S., 22 F. Supp. 424 (Ct. Cl. 1938); St. Nicholas Club of City of New York v. U. S., 22 F. Supp. 434 (Ct. Cl. 1938); Union Club Co. v. U. S., 21 F. Supp. 412 (Ct. Cl. 1937); Transportation Club of San Francisco v. U. S., I7 F. Supp. 201 (Ct. Cl. 1936); Century Ass'n v. Anderson, ro F. Supp. roo5 (S. D. N. Y. 1935); Chicago Engineers' Club v. U. S., 9 F. Supp. 680 (Ct. Cl. I935); Chance v. U. S., 9 F. Supp. IorI (Ct. Cl. I935); University Club, City of Washington, D. C. v. U. S., 6 F. Supp. I29 (Ct. Cl. 1934); The Lambs v. U. S., 8 F. Supp. 737 (Ct. Cl. 1934); Sagninaw Club v. U. S., 7 F. Supp. 302 (Ct. Cl. 1934); Town Club of St. Louis v. U. S., 68 F. (2d) 620 (C. C. A. 8th, I934); Union League Club of Chicago v. U. S., 4 F. Supp. 929 (Ct. Cl. 1933); Wichita Conmercial \& Social Club Ass'n v. U. S., 2 F. Supp. 476 (Ct. Cl. I933); Quadrangle Club v. U. S., 64 F. (2d) 80 (C. C. A. 7th, I933); Quinnipiack Club v. U. S., 4 F. Supp. 996 (Ct. Cl. 1933); Phi Gamma Delta Club v. U. S., 5 F. Supp. 140 (Ct. Cl. 1933); Army and Navy Club of America v. U. S., 53 F. (2d) 277 (Ct. Cl. I93X), cert. denied, 285 U. S. 548 (1932); Women's University Club of Seattle v. Poe, 52 F. (2d) 447 (W. D. Wash. 193I); Fleming v. Reinecke, 52 F. (2d) 449 (C. C. A. 7 th, 1931), cert. denied, 284 U. S. 689 (1932); Women's University Club v. U. S., 50 F. (2d) 469 (Ct. Cl. 193I); Abbott v. U. S., 66 Ct. Cl. 603 (1929), cert. denied, 280 U. S. 554 (I920); Fisler v. U. S., $66 \mathrm{Ct}$ Cl. 220 (1928), cert. denied, 279 U. S. 836 (I929); Faculty Club of University of California v. U. S., 65 Ct. Cl. 754 (1928). Clubs held not social: Union Club of Pittsburgh v. Heiner, $99 \mathrm{~F}$. (2d) 259 (C. C. A. 3d, I938) (businessmen's lunches); Krug v. Rasquin, 2I F. Supp. 866 (E. D. N. Y. I937) (business); Century Club v. U. S., I2 F. Supp. 6x7 (Ct. Cl. I935) (business and civic); Squantum Ass'n v. Page, 7 F. Supp. 815 (D. R. I. I934), affd, 77 F. (2d) 918 (C. C. A. rst, 1935) (serving food); Whitehall Lunch Club v. U. S., 9 F. Supp. I32 (Ct. Cl. x934); Tidwell v. Anderson, 72 F. (2d) 684 (C. C. A. 2d, 1934) (faculty club); Houston Club v. U. S., 58 F. (2d) 487 (Ct. Cl. I932) (business); Builders' Club of Chicago v. U. S., 58 F. (2d) 503 (Ct. Cl. r932) (anti-labor union activities); TwoThirty-Three Club v. Welch, 2 F. Supp. 963 (S. D. Cal. r932) (civic and philanthropic); The Cordon v. U. S., 46 F. (2d) $7 \times 9$ (Ct. Cl. I93I) (art); Los Angeles City Club v. Welch, 44 F. (2d)' 239 (S. D. Cal. 1930) (civic); Cosmos Club v. U. S., 42 F. (2d) 321 (Ct. Cl. 1930) (educational); Washington Club v. U. S., 49 F. (2d) 656 (Ct. Cl. I930) (educational and cultural); Bankers' Club of America v. U. S., $37 \mathrm{~F}$. (2d) 982 (Ct. Cl. 1930) (meals for businessmen); Aldine Club v. U. S., $65 \mathrm{Ct}$. Cl. 315 (1928) (businessmen's lunches); City Club of St. Louis v. U. S., 24 F. (2d) 743 (E. D. Mo. I928) (civic); Chemists' Club v. U. S., 64 Ct. Cl. 156 (Ig27) (scientific). 
club, $^{74}$ but the mere possession or use of a gymnasium, swimming pool, or other athletic facilities by a club whose exclusive or predominant purpose is religion or philanthropic social service will not bring it within the taxable class. ${ }^{75}$ Although the administrative application of this test has been contested before the courts in several instances, ${ }^{76}$ it is considerably easier to apply than the one relating to social clubs. A health club, with elaborate facilities, is probably near the borderline, but it would seem that it might well be classed as an athletic or sporting club. ${ }^{\mathbf{7 7}}$

From the standpoint of tax avoidance, a very important question is that of whether a club can insulate its members from this tax by reorganizing into a corporaton for profit, with the so-called members being relegated to the position of mere privilege holders who have no interest in the club property and no voice in its management. The argument in support of avoidance on this basis is that the dues tax statute was intended to apply only with respect to clubs the members of which have rights in the club property or at least a voice in the management or operation of the facilities. In a recent case, ${ }^{78}$ the club was a corporation for profit, with its stock closely held, and the playing members, who were limited in number, had no interest in the club property and took no part in the management of the affairs of the corporation. The contention was that, as the corporation was an organization for profit, it could not be regarded as a social, athletic, or sporting club and that its members were therefore immune from this tax. The court, pointing out the taxavoidance implications of such a contention, held that the members as a group, rather than the corporation, constituted a sporting club and that their dues were taxable. Apparently, then, the mere fact that the club is organized as, or reorganized into, a corporation will not shield the members from tax; but if, under such circumstances, there is no association or cooperation among the members toward a common objective, they will not be held to constitute such an organization. ${ }^{78}$

Differentiation between taxable dues and nontaxable fees is often extremely diffcult. The statute ${ }^{80}$ provides that the term "dues" includes assessments, regardless of their purpose, but it sheds no light on the treatment to be accorded special, additional fees or payments. An' additional fee that is applicable to each member of a particular class, ${ }^{81}$ or that is an incident to membership of a particular class, ${ }^{82}$ is taxable. Moreover, even though the fee is not an incident to the membership, if the obligation to pay it continues until notice is given that the special privileges will no longer be used and if the member is subject to expulsion for failure to pay it, as in the case of his regular dues, the fee will be treated as dues. ${ }^{83}$ But if the payment of the fee is

74 U. S. Treas. Reg. 43 (1940) \$ror.39. ${ }^{\pi} 1$ lbid.

${ }^{78}$ Clubs held athletic or sporting: Bunker Hill Country Club v. U. S., 9 F. Supp. 52 (Ct. Cl. 1934), cert. denied, 296 U. S. 583 (I935); Camp Fire Club of America v. U. S., I F. Supp. 782 (Ct. Cl. 1932); Block Hall, Inc. v. U. S., 57 F. (2d) 918 (C. Cl. 1932). Contra: Arner v. Rogan, 404 C. C. H. \$9567 (S. D. Cal. 1940).

${ }^{78}$ Bunker Hill Country Club v. U. S., sttpra note 76.

${ }^{79}$ Anner v. Rogan, stupra note 76. ${ }^{77}$ Cf. Arner v. Rogan, stupra note 76.

${ }^{82}$ G. C. M. 7507 , IX-2 C. B. $4^{\mathrm{I}} 4$ (x929).

${ }^{82}$ Foran v. McLaughlin, 59 F. (2d) 158 (C. C. A. 9 th, 1932).

${ }^{83}$ Hardt v. McLaughlin, 25 F. Supp. 684 (E. D. Pa. 1936); Merion Crickct Club v. U. S., 404 C. C. H. $₫ 9207$ (E. D. Pa. I940). 
optional, $^{84}$ or if the so-called assessment is actually voluntary, ${ }^{85}$ the amount is not taxable.

\section{Initiation Fees}

The $\operatorname{tax}^{86}$ relating to initiation fees has been held to be an excise tax on the enjoyment of a privilege. ${ }^{87}$ Prior to an amendatory ${ }^{88}$ definition of the term "initiation fees," this tax was being avoided ${ }^{89}$ by requiring new members to purchase a share of stock or a bond in lieu of an ordinary initiation fee..$^{00}$ The amendment provides that such fees include any payment, contribution or loan required as a condition precedent to membership, whether or not evidenced by a certificate of interest or indebtedness or share of stock, and irrespective of the person or organization to whom paid, contributed or loaned. It is immaterial that the stock ${ }^{91}$ or certificate ${ }^{92}$ of membership is purchased from a retiring member by the new member and that the payment is made to the retiring member rather than to the club itself. Moreover, the payment of the fee need not be a condition precedent to membership of all classes; ${ }^{03}$ it is enough if it is required for one particular class. ${ }^{94}$ The constitutionality of this tax has been contested and upheld. ${ }^{95}$

\section{Life Memberships}

The $\operatorname{tax}^{96}$ on life memberships has been variously described as a tax on the privilege $^{97}$ to share in the club facilities or on the enjoyment ${ }^{98}$ of a privilege. Inasmuch as this tax applies whether or not the membership privileges are ever exercised, ${ }^{09}$ it would be more precise to say that the tax is imposed simply with respect to a person's having a life membership. ${ }^{100}$ Resignation or transfer of membership, without more, is not sufficient to cut off further tax liability. It will continue until the club accepts the resignation or recognizes the transfer. ${ }^{101}$ As may be supposed, the application of this tax to life memberships acquired before the effective date of

84 White v. Winchester Country Club, II7 F. (2d) I46 (C. C. A. Ist, I94I); Williamson v. U. S., I2 F. Supp. 26 (W. D. N. C. I934); Baltimore Country Club v. U. S., 7 F. Supp. 607 (D. Md. 1934); Weld v. Nichols, 9 F. (2d) 977 (D. Mass. 1925).

${ }^{86}$ Pendennis Club v. U. S., 20 F. Supp. 758 (W. D. Ky. x937); Fresh Meadow Country Club v. U. S., I7 F. Supp. 400 (E. D. N. Y. 1936); Garden City Golf Club v. Corwin, 62 F. (2d) 246 (C. C. A. 2d, r932).

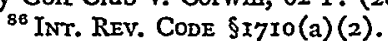

87 Wing Lodge v. Blacklidge, 59 F. (2d) 42 I (C. C. A. 7th, I932); Munn v. Bowers, 47 F. (2d) 204 (C. C. A. 2d, 193I), cert. denied, 283 U. S. 845 (I93I). Cf. S. T. 904, stzpra note 70.

${ }^{88}$ Revenue Act of $1928, \$_{4} \mathrm{r}_{3}(\mathrm{a})$.

${ }^{80}$ H. R. Rep. No. 2, 70th Cong., Ist Sess. (1928) 26.

${ }^{00}$ See Masonic Country Club of Western Michigan v. Holden, 18 F. (2d) 553 (C. C. A. 6th, 1927); Derby v. U. S., I7 F. (2d) Ir9 (Mass. I927); Alliance Country Club v. U. S., 62 Ct. Cl. 579 (1926); Luken v. U. S., 62 Ct. Cl. 598 (1926); Page v. U. S., 62 Ct. Cl. 590 (I926).

'Wing Lodge v. Blacklidge, Munn $\nabla$. Bowers, both supra note 87 .

${ }^{03}$ Knollwood Club v. U. S., 74 Ct. Cl. I (I93I).

${ }^{03}$ S. T. 387, I-2 C. B. 29 I (I92I).

of Wing Lodge v. Blacklidge, Munn v. Bowers, both supra note 87 .

${ }^{D O}$ INT. REV. CODE $\$$ I YIO(a) (3).

${ }^{07}$ Multnomah Athletic Club v. Huntley, 47 F. (2d) 352 (D. Ore. 1930).

${ }^{08}$ MacLaughlin v. Williams, 52 F. (2d) 724 (C. C. A. 3d, I93I), cert. denied, 284 U. S. 681 (I932). See also McCaughn v. Williams, 23 F. (2d) 840 (C. C. A. 3d, I928), cert. denied, 276 U. S. 629 (1928). ${ }^{00}$ Multnomah Athletic Club v. Huntley, supra note 97.

${ }^{100}$ Cf. INT. Rev. CODE $\$ \S I 410,1520,1600$.

${ }_{101}$ S. T. 684 , XII-I C. B. 454 (I932). 
the statute has been contested on the grounds that the tax is a direct tax or is retroactive. In view of the nature of the thing taxed, there is no basis for either of these contentions. ${ }^{102}$

\section{Playing Cards and Safe Deposit Boxes}

The administration of the statute imposing the tax ${ }^{103}$ on playing cards does not appear to be attended by any special difficulties. Nevertheless, as any person who offers or exposes for sale playing cards to which revenue stamps are not affixed is classed ${ }^{104}$ as a manufacturer and is accordingly under the duty to affix stamps thereto upon sale, it is quite likely that there is some evasion of the tax, either through ignorance or otherwise, particularly on the part of clubs and similar organizations which repurchase and resell decks of cards. There seems to be no evidence that the Bureau encounters any difficulty in the administration of the statute ${ }^{105}$ which imposes the tax with respect to safe deposit boxes.

\section{Tobacco, Snuff, Cigars, and Cigarettes}

The taxes ${ }^{106}$ with respect to manufactured tobacco products date back, through an unbroken period, to $1862 .{ }^{107}$ As the formative stage of these taxes has thus long since been passed and as administrative officials and industry members, by virtue of almost eighty years' experience, are thoroughly familiar with the requirements of the law, present-day administration in this field is attended by a minimum of difficulties. Despite the implications of the tax-imposing provisions ${ }^{108}$ that (in the case of domestic products, for example) the tax is on the manufacture and sale or removal or on the sale or removal alone, it has been established ${ }^{108}$ that the taxable transaction is the manufacture or importation. Sale or removal from the factory or customs house simply fixes the time for tax payment. This postponement of payment, it has been said, ${ }^{110}$ is designed to mitigate the burden on the manufacturer or importer. A consequence of the nature of the taxable transaction is that tobacco products sold by a manufacturer to a state are taxable; for in such a case the effects of the tax are incidental, indirect, and permissible. ${ }^{111}$ The stamps used in connection with the payment of the tobacco taxes are not mere receipts evidencing prior payment of the tax; they are actually the means, through affixation, of tax payment..$^{112}$

The tobacco statute is unique among revenue measures in that it provides ${ }^{113}$ that no package of a manufactured product shall contain or have attached thereto any paper, certificate, lottery ticket, or indecent or immoral picture. The validity of the

${ }^{102}$ Multnomah Athletic Club v. Huntley, stipra note 97; MacLaughlin v. Williams, McCaughn v. Williams, both supra note 98 .

103 INT. REv. CODE $\$ \S I 800, x 807$. $2041 d$. $\$ 1831(a)$.

${ }^{105}$ Id. c. 12.

107 Act of July I, I862. The tax in respect of cigarette papers and tubes imposed by INT. REv. ConE $\$ 2000$ (d) was not, however, enacted until I917. Revenue Act of 1917, $\$ 404$.

${ }^{108}$ See INT. Rev. Code $\$ 2000$ (a) (c) (d).

${ }^{109}$ Liggett \& Myers Tobacco Co. v. U. S., 299 U. S. 383 (I937).

${ }^{110}$ Ibid.

${ }^{212}$ American Tobacco Co. v. U. S., 166 U. S. 468, 476, 477 (I897).

${ }^{213}$ INT. REV. CODE $\$ \$ 2100(d), 2 I I I(c)$. 
forerunner of this provision was vigorously assailed on the ground that, as the coupons involved in that case ${ }^{114}$ were of an inappreciable weight and therefore did not interfere in any way with the determination of the tax base, ${ }^{115}$ Congress had no authority to prohibit their enclosure. The Court, however, held otherwise, saying that Congress had full power to prescribe that a package required to bear a revenue stamp shall contain only the taxable article.

\section{Oreomargarine}

A purpose of the oleomargarine taxes, ${ }^{116}$ which can scarcely be characterized as secondary, is to discourage, by heavier taxation, ${ }^{117}$ the manufacture of colored oleomargarine ${ }^{118}$ in order to reduce the opportunities for its fraudulent distribution to the public as butter and also to assure, by the branding requirements, ${ }^{119}$ that taxpaid oleomargarine cannot readily be sold as butter. Available evidence indicates that this purpose has been substantially achieved. While this statement does not mean that the production of colored oleomargarine has been suppressed, ${ }^{120}$ it is true that the trade is principally confined to uncolored oleomargarine. ${ }^{121}$ The tax ${ }^{122}$ on that product is so low that it probably bas not retarded or adversely affected the trade. The Supreme Court, early upholding the constitutionality of these taxes, ${ }^{123}$ declared that if a tax is within the lawful power of Congress, the exercise of that power may not be judicially restrained because of the results to arise therefrom, and that it would not inquire into the motive or purpose of Congress in enacting these taxes. ${ }^{124}$ Although classification problems have arisen in the past, ${ }^{125}$ it would appear that recent amendments ${ }^{126}$ have largely removed the grounds for such controversies. On the other hand, problems frequently arise under the provision ${ }^{127}$ denominating as a manufacturer any person who adds to or mixes with oleomargarine a substance that gives it a yellow color and supplies it to others. In some instances, as where the person is the proprietor of a boarding house, it is clear that the violations occur through ignorance, but in others it is equally clear that the offender had full knowledge of the requirements of the law..$^{128}$

\footnotetext{
${ }^{114}$ Felsenheld v. U. S., 186 U. S. 126 (x902).

${ }^{210}$ The tax base is quantitative. See INT. REv. CODE $\$ 2000$.

${ }^{110}$ INT. REV. CODE $\$ 2301(\mathrm{a})(\mathrm{I}), 2306$. ${ }_{117}$ Id. \$230I(a)(I).

${ }^{118}$ For definition of colored oleomargarine, see id. $\$ 2301$ (a) (2).

${ }^{2100}$ Id. $\$ \$ 2302$ (b) (2) (3), 2304(b), 2306; and also U. S. Treas. Reg. No. 9 (1936) arts. 29, 54, and 80.

${ }^{120}$ During the fiscal year $1940,1,859,93$ I pounds of colored oleomargarine were produced. REP. Con'r INT. Rev. (x940) 26.

${ }^{121}$ The production of uncolored oleomargarine for the fiscal year 1940 amounted to $301,857,570$ pounds. Ibid.

${ }^{123}$ MícCray v. U. S., I95 U. S. $27(1904)$. ${ }^{221}$ Id. at 59.

${ }^{235}$ Product taxable: National Foods v. U. S., 13 F. Supp, 364 (Ct. Cl. x936), cert. denied, 299 U. S. 544 (1936); Harrow-Taylor Butter Co. v. Crooks, 4I F. (2d) 627 (C. C. A. 8th, 1930); John F: Jelke Co. v. U. S., 63 Ct. Cl. 370 (r927); Wm. J. Moxley v. Hertz, 216 U. S. 344 (I9ro); Cliff v. U. S., T95 U. S. 159 (1904). Product not taxable: Miller v. Standard Nut Margarine Co., 284 U. S. 498 (1932); Foley v. Miller, 24 F. (2d) 722 (S. D. Ohio 1928); Higgins Manufacturing Co. v. Page, 297 Fed. 644 (D. R. I. 1924); Braun \& Fitts v. Coyne, I25 Fed. 33 I (N. D. Ill. I899).

${ }_{120}$ Act of July $10,1930, \S 1,{ }_{4}^{6}$ STAT. I022 (definition of oleomargarine), and Act of Mar. 4, 193I, $\$ 2$, 46 STAT. 1549 (determination of yellowness). These amendments are found in INT. REv. Code $\$ \$ 2300$ and $2301(a)(2)$, respectively. ${ }_{227}^{27}$ NT. REv. CODE $\$ 2302$ (a).

${ }_{128}$ Discussion of the closely related taxes on adulterated butter, process or renovated butter, filled cheese
} 


\section{Narcotics}

The administration of the narcotic laws, ${ }^{129}$ from the standpoint of their enforcement, is vested in the Bureau of Narcotics, while the Bureau of Internal Revenue is concerned primarily with tax collections, adjustments, and compromises. Enforcement problems encountered by the Bureau of Narcotics are outside the scope of this paper.

The narcotic taxes apply to narcotic drugs, ${ }^{130}$ smoking opium, ${ }^{131}$ and marihuana. ${ }^{132}$ Although the statutes imposing these taxes are regulatory in purpose and effect, the yield ${ }^{133}$ from the tax on narcotic drugs is quite considerable, as such drugs are extensively used in the field of medicine. On the other hand, the requirements ${ }^{134}$ of the smoking-opium statute are such that apparently noione has ever qualified as a manufacturer thereunder, and the collections ${ }^{135}$ under the marihuana tax are so insignificant as to indicate that lawful traffic in marihuana is very restricted.

Subject to certain exceptions, narcotic drugs may be transferred only in pursuance of a written order from the transferee, prepared on a form furnished by the Government. ${ }^{136}$ The exceptions include registered physicians ${ }^{137}$ dispensing such drugs to their patients in the course of their professional practice, and dealers ${ }^{138}$ transferring such drugs to consumers under prescriptions issued by registered physicians. Moreover, the forms for such orders may be issued only to persons who have registered and paid tax under the occupational tax statute. ${ }^{130}$ The validity of the order requirements has been upheld by the Supreme Court in two famous cases. ${ }^{140}$ These requirements tend to keep the traffic aboveboard, subject to inspection by Government agents, and to diminish the opportunity of unauthorized persons to obtain the drugs and sell them clandestinely without paying the tax. ${ }^{141}$ Thus, there was no basis for the contention that such requirements had nothing to do with facilitating the collection of revenue. ${ }^{142}$ Furthermore, as the legislation had some reasonable relation to the exercise of the taxing power, the supposed motives which induced it were not grounds for its invalidation. ${ }^{143}$

The requirement ${ }^{144}$ in the smoking-opium statute that the manufacturer must

and mixed flour is omitted in the interest of space. The taxes on coconut and other vegetable oils are omitted as not falling within the definable limits of consumption taxation. See Studenski, Characteristics, Developments and Present Status of Consumption Taxes, supra this issue, for an attempt to define the field. So also of the taxes on firearms. Cf. discussion of bituminous coal taxes, infra.

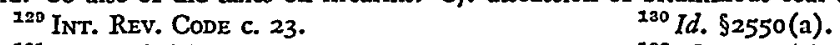

${ }^{133}$ Collections, including occupational taxes, for the fiscal year 1940 were $\$ 605,395.66$. Rep. Com'r INT. REV. (I940) $25 . \quad{ }^{134}$ INT. REV. CoDE $\$ \$ 2567$ (a), 2569 (b)(c)(d). ${ }^{135}$ Collections, including occupational taxes, for the fiscal year I940 were $\$ 4,702.60$. REP. CoM'n INT. REv. (I940) 25.

${ }^{136}$ INT. Rev. CODE $\$ 2554$. Cf. id. $\$ 259 \mathrm{I}$, requiring orders for transfers of marihuana.

${ }^{137} \mathrm{Id} . \$ 2554(\mathrm{c})(\mathrm{I})$.

${ }^{138}$ Id. $\$ 2554(\mathrm{c})(2)$. $\quad{ }^{130}$ Id. $\$ 2554(\mathrm{f})$.

${ }^{140}$ U. S. v. Doremus, 249 U. S. 86 (I9rg); Nigro v. U. S., 276 U. S. 332 (1928).

${ }^{141}$ See U. S. v. Doremus, supra note I4̧0.

142 Ibid.

14" INT. Rev. CoDe $\$ 2569$ (c). 
be a citizen has been upheld. ${ }^{145}$ The Constitution does not require Congress to extend such privilege to a noncitizen. ${ }^{146}$ Another case ${ }^{147}$ under this statute is an object lesson for all taxing authorities. Regulations implementing the general requirements of a destructive tax measure are as necessary as similar regulations under a statute designed solely for revenue purposes. Unless such requirements are so implemented, there is no way that compliance may be had with them and consequently they may be disregarded with impunity. ${ }^{148}$

\section{White Phosphorus Matches}

The original purpose of the statute ${ }^{149}$ with respect to white phosphorus matches, which was to suppress the production of poisonous matches, has long since been completely accomplished, as there have been no manufacturers of these matches and no collections under this statute for many years. The use of white phosphorus in the manufacture of matches caused necrosis, or "phossy jaw," a painful and disfiguring disease, while the matches themselves were efficient instruments of selfdestruction and a constant menace to children. The humanitarian action by the company which controlled the use of a harmless substitute, in surrendering its letters patent to the Government, now enables all manufacturers to use this compound without payment of royalties.

\section{LIQUOR}

Although the liquor taxes ${ }^{150}$ produce well over one-half billion dollars per year, ${ }^{151}$ the provisions imposing such taxes are at the same time highly regulatory, both in purpose and effect. But, here, regulation is resorted to primarily as a true incident of the taxing power rather than to accomplish a nonrevenue purpose; that is, the regulation is designed to protect the revenue and to facilitate its collection. Nevertheless, in view of the great extent to which the liquor industry is subjected to rigid, detailed statutory provisions and voluminous regulations, and the litigious disposition of many a businessman chafing under governmental regulation regardless of its purpose, it might be supposed that the administration of the liquor laws is accompanied by a ceaseless flow of administrative rulings and by interminable litigation. The remarkable fact, however, is that the lawful or qualified industry members, almost without exception, follow the letter of the law and the exceedingly detailed regulations down to the last bitter period. The explanation of this phenomenon would seem to be more involved than in the case of the tobacco taxes. Undoubtedly it is due in part to the fact that the taxpayers, through many years of experience, are thoroughly familiar with the requirements of the law and regulations. It is probably due mainly, however, to a feeling on their part that they are on probation and that

\footnotetext{
${ }^{145}$ Lee Mow Lin v. U. S., 250 Fed. 695 (C. C. A. 8th, I918), cert. denied, 247 U. S. 518 (1918).

${ }^{140}$ Ibid.

${ }^{167}$ Chin Sing v. U. S., 227 Fed. 397 (C. C. A. 7th, I915).

${ }^{168}$ Ibid. - ${ }^{140}$ INT. REV. CODE C. 24. INT. REV. (I940) I, 2.
} 
it is definitely to their interests to meet all demands of the Government without protest or resistance.

The major problem in this field is an enforcement problem having to do with illicit producers of distilled spirits. These persons, who carry on their operations entirely outside the law, fall into two principal classes-"moonshiners" in remote, mountainous regions, and remnants of the Prohibition-era gangs in the larger cities. The serious proportions of this problem are clearly indicated by statistics as to seizures and arrests. ${ }^{152}$ Nevertheless, the Government is making definite headway in its effort to suppress the illicit production of distilled spirits. Compared with the fiscal year 1939, still seizures decreased rr.6 per cent, mash seizures $x 9.8$ per cent, and arrests II.I per cent in $1940 .{ }^{153}$ Enforcement progress is further evidenced by mash seizures during the past five years, which decreased 67 per cent. ${ }^{154}$ A very effective weapon is afforded the Government by the provision ${ }^{155}$ requiring dealers in raw materials for the production of distilled spirits to furnish the Government with the names and addresses of persons to whom such materials are distributed. In the fiscal year 1940, information furnished by such dealers led to the seizure of more than 500 illicit distilleries and 150 vehicles, and to more than 700 arrests. ${ }^{150}$

\section{Manufacturers' Excises}

The manufacturers' excise taxes ${ }^{167}$ are imposed upon various classes of articles ${ }^{168}$ sold by the manufacturer, producer, or importer, or, in the case of electrical energy, by the vendor. Moreover, these taxes apply, by reason of sections other than the tax-imposing provisions, to leases ${ }^{159}$ of such articles and to the use ${ }^{100}$ thereof by manufacturers, producers, or importers. The language of the tax-imposing provisions has in the past occasioned some uncertainty as to the precise nature of the taxable transaction. An early interpretation ${ }^{161}$ was that such transaction was the manufacture of the article. A later contention ${ }^{162}$ had it that the transaction consisted in the manufacture (or production or importation) and the sale of the article. The present view, ${ }^{163}$ resulting from a decision ${ }^{164}$ of the Supreme Court, is that where a sale, for example, is involved, the transaction is simply the sale. The payment of these taxes is required to be made by the manufacturer, producer, or importer, or, in the case of electrical energy, by the vendor. ${ }^{165}$

${ }^{153}$ During the fiscal year 1940 , investigators seized 10,663 stills, with an aggregate mash capacity of $x, 653,775$ gallons; $6,480,240$ gallons of mash; 264,594 gallons of spirits; and 4,523 automobiles and trucks. This property totaled an aggregate appraised value of over $\$ 2,000,000$ dollars. In the same period, 25,638 persons were arrested. Id. at 34 .

${ }^{153}$ Ibid.

${ }^{165}$ INT. REv. CoDE $\$ 28 \mathrm{rr}$.

154 Ibid.

${ }^{250}$ ReP. Com'R INT. Rev. (1940) 34.

${ }^{187}$ INT. REv. CODE C. 29-A. The sugar tax, while levied on manufacture rather than sale, is treated for most purposes as a manufacturers' excise. The principal difference arises with respect to sales to governmental bodies. See note 271 , infra.

${ }^{158}$ These articles are specified in $i d . \$ \$ 3400-34 \times 3 . \quad{ }^{150} \mathrm{Id}$. $\$ 3440$.

${ }^{100}$ Id. \$3444.

${ }^{102}$ Indian Motorcycle Co. v. U. S., 283 U. S. 570, 574 (r93r).

${ }^{108}$ U. S. Treas. Reg. 46 (1940) $\$ \$ 316.30,316.40,316.50,316.70,316.80$.

${ }^{104}$ Indian Motorcycle Co. v. U. S., supra note 162.

${ }^{105} \mathrm{See}$ U. S. Treas. Reg. 46 (1940) $\$ 316.3 ;$ id. 44 (1939) $\$ 314.3 ;$ id. 42 (1932) art. 41 , c. v, as amended by T. D. 4393 . 


\section{Tires and Inner Tubes}

The $\operatorname{tax}^{168}$ relating to tires and inner tubes is measured by the weight of the article. Although this weight basis operates fairly in most instances, its application to tires for children's vehicles such as wagons and scooters is somewhat inequitable. In the case of such tires the tax may well equal nearly one-half their cost, whereas the tax on automobile tires is obviously a much smaller percentage of their cost. As this tax applies to tires for any vehicle, ${ }^{167}$ all tires are taxable unless the thing on which they are mounted is incapable of use as a means of transporting a person or burden. ${ }^{168}$

A question that has caused some difficulty in connection with the administration of the statute imposing this tax is whether retreaded tires are subject to taxation. Formerly, the Bureau's position ${ }^{\mathbf{1 6 9}}$ with respect to this matter was that if the retreading operation destroyed the original identity of the tire, the process was manufacturing or production and the tire was taxable. ${ }^{170}$ Recently, however, the Bureau has abandoned this position in favor of another test developed judicially ${ }^{171}$ in respect of automobile parts produced from junk material. Under the new test, if a person produces a tire from scrap, salvage, or junk material by processing, manipulating, or changing the form of the article or by combining or assembling two or more articles, he is a manufacturer and the tire so produced is taxable. ${ }^{172}$ Another question arising under the statute imposing this tax is whether a mileage contract is a lease. ${ }^{173}$ Under such a contract the tire manufacturer supplying the tires retains title thereto and agrees to service them during the term of the contract, while the bus company agrees to pay for the use of the tires at a specified rate per mile and to purchase them at the end of the contract at the list price, less the mileage amount theretofore paid under the contract. Such a contract has been ruled to be a lease for the purposes of this tax and the tires furnished thereunder declared taxable, ${ }^{174}$ the tax liability being incurred upon the delivery of the tires. ${ }^{175}$

\section{Toilet Preparations}

One of the chief difficulties in connection with administering the statute imposing the $\operatorname{tax}^{178}$ on toilet preparations has been the determination, in special instances, of who is the manufacturer. If $M$ Company arranges to have a product manufactured by $X$ Company according to its specification and for sale under its name, ${ }^{17 \tau}$ or if it furnishes ingredients for a product to be manufactured for it by $Y$ Company, ${ }^{178}$

${ }^{100}$ INT. REV. CODE $\$ 3400$.

${ }^{107}$ S. T. 660 , XII-I C. B. 385 (1932). Cf. S. T. 465, XI-2 C. B. 454 (193x).

${ }^{108}$ Ibid.

${ }^{200}$ S. T. 812 , XIV-I C. B. 406 (I934); S. T. 648 , XII-I C. B. 384 (1932).

${ }^{120}$ Cf. Skinner v. U. S., 8 F. Supp. 999 (S. D. Ohio 1934). Although the court in this case employed broad language to the effect that the tax is limited to new tires, the actual decision was not inconsistent with the Bureau's earliest test, as the original identity of the tires there involved had not in fact been destroyed.

${ }_{171}$ Clawson \& Balls v. Harrison, 108 F. (2d) 991 (C. C. A. 7th, 1939).

${ }^{172}$ U. S. Treas. Reg. 46 (I940) $\$ 316.4$. See also S. T. 896, 1940-I C. B. 252.

${ }^{173}$ See INT. Rev, CoDe $\$ 3440$.

${ }^{174}$ G. C. M. II 410, XII-I C. B. $3^{82}$ (1932); S. T. 496 , XI-2 C. B. 455 (193I).

${ }^{175}$ S. T. 496 , supra note 174 .

${ }^{177}$ G. C. M. 16223, XV-I C. B. 380 (1935). $\quad{ }^{178}$ G. C. M. I1522, XII-I C. B. 387 (I932). 
$M$ Company is deemed to be the manufacturer of the product. On the other hand, if $N$ Company buys a product from $A$ Company and packages it itself under its trade name, ${ }^{170}$ or if it buys a product manufactured and packed for it by $B$ Company, ${ }^{180}$ or if it merely furnishes the containers for a product to be manufactured for it by $C$ Company, ${ }^{181} \mathrm{~N}$ Company is held not to be the manufacturer of the product. A druggist may treat as exempt from this tax a preparation compounded by him pursuant to a prescription, as it is assumed that a bona fide prescription is written for medical purposes. ${ }^{182}$ But where the physician specifies on the prescription that the preparation is for toilet purposes, the druggist is regarded as the manufacturer. ${ }^{183}$ Beauty shops and barber shops are permitted to add water to a taxpaid toilet preparation without incurring liability as a manufacturer, if such addition is made as part of the business of rendering personal service to their patrons. ${ }^{184}$ However, if the addition of water is in any such case done for the purpose of preparing the article for sale rather than use in business, the shop is held to be a manufacturer. ${ }^{185}$

This tax, being applicable solely to sales made by manufacturers, producers, or importers, operates with discriminatory effects that probably were not within the contemplation of Congress. A manufacturer who produces and sells products in bulk naturally makes his sales on a much lower price level than does a manufacturer producing and packaging his product. As this tax is based on price rather than quantity, the first manufacturer bears a much lighter tax burden than the second. It scarcely needs to be pointed out that certain manufacturers have taken advantage of this situation to minimize their taxes. In order to safeguard the revenue and to obviate the inequity under consideration, it might well be advisable to extend this tax to persons who package toilet preparations in the form in which they are sold to consumers, whether or not such persons are the actual producers.

The statute provides that the price of toilet peparations shall include, among other items, any charge for coverings and containers, if furnished by the actual manufacturer. ${ }^{186}$ Questions have arisen as to whether certain special containers of cosmetics, such as cigarette and vanity cases, are taxable. Formerly, the test used by the Bureau in these cases was the comparative value of the cosmetics and the container. ${ }^{187}$ The present test, however, is that of the dominant or primary purpose of the container. ${ }^{188}$ Under this test, if the container, no matter how valuable, serves no useful purpose other than as a covering, the charge therefor is includible in the tax basis.

As may be supposed, the Bureau has frequently encountered problems involving the classification of products for the purposes of this tax. It has been ruled that taxable products include preparations to cover birth marks, ${ }^{189}$ baby powder, ${ }^{100}$

\footnotetext{
${ }^{170}$ Williams v. Harrison, Iro F. (2d) 989 (C. C. A. 7 th, I940).

${ }^{180}$ Charles Marchand Co. v. Higgins, 36 F. Supp. 792 (S. D. N. Y. 1940). See also G. C. M. II522, stupra note I78.

181 G. C. M. 11522 , supra note $\times 78$.

183 Ibid.

${ }^{185}$ Ibid.

${ }^{187}$ S. T. 559, XI-2 C. B. 459 (I93 I).

${ }^{182}$ S. T. 478, XI-2 C. B. 456 (193I).

${ }^{184}$ S. T. $825, X V-1$ C. B. 382 (1935).

${ }^{180}$ INT. REV. CODE $\$ 3401$.

${ }^{188}$ S. T. 815, XIV-2 C. B. 365 (1934).

${ }^{189}$ G. C. M. 10960, XI-2 C. B. $45^{8}$ (I93I).

${ }^{100}$ S. T. 693 , XII-2 C. B. 312 (1932).
} 
hydrogen peroxide, ${ }^{191}$ permanent-waving solutions, ${ }^{192}$ and cocoa butter. ${ }^{193}$ On the other hand, this tax has been held not to apply to a germicidal solution ${ }^{194}$ or to styptic pencils. $^{105}$ If an article may be used both for medicinal and toilet purposes, it is taxable, irrespective of its chief use. ${ }^{196}$

Parts and Accessories, Automobile and Truck Bodies, etc.

The tax ${ }^{107}$ with respect to parts and accessories has given rise to considerable litigation and numerous administrative rulings. The principal difficulties have to do with the question whether a person who produces parts from scrap, salvage, or junk material is a manufacturer and with the classification of articles as taxable or nontaxable. The earlier test ${ }^{198}$ with regard to the first problem was whether the processing operations destroyed the original identity of the article. That test was superseded in 1940 by an entirely different test ${ }^{199}$ based on a 1939 decision $^{200}$ of the circuit court of appeals for the Seventh Circuit. The position of the Bureau at present in regard to this problem is that if a person produces a part from scrap, salvage, or junk material by processing, manipulating, or changing the form of an article or by combining or assembling two or more articles, he is a manufacturer and the article so produced is taxable. Nevertheless, there are indications that the foundation of the new test is as yet none too secure, for on at least two occasions district courts have refused to follow it. ${ }^{201}$

The task of delimiting the field of taxable parts and accessories by the case-by-case method was considerably facilitated by the provision ${ }^{202}$ in the Revenue Act of 1932 that spark plugs, storage batteries, ${ }^{203}$ leaf springs, coils, ${ }^{204}$ timers, ${ }^{205}$ and tire chains, ${ }^{206}$ suitable for use on automobiles, trucks, taxable tractors, or motorcycles, are to be considered parts or accessories. The extent to which the case-by-case method has been used and the results obtained are indicated by the partial list of recent decisions and rulings set forth in the margin. ${ }^{207}$ While the boundaries of this area

101 Peroxide Chemical Co. v. Sheehan, I08 F. (2d) 306 (C. C. A. 8th, I939).

102 Duradene Co. v. Magruder, 2 I F. Supp. 426 (Md. 1937), aff'd, 95 F. (2d) 999 (C. C. A. $4^{\text {th }}$, I938); S. T. $8 \mathrm{r} 8$, XIV-2 C. B. 366 (1934). ${ }^{103}$ S. T. 506, XI-2 C. B. 457 (I93I).

${ }_{104}$ Sharp \& Dohme v. Ladner, 82 F. (2d) 733 (C. C. A. 3d, I936).

${ }^{105}$ S. T. 497, XI-2 C. B. 457 (r93I).

100 S. T. 655 , XII-I C. B. 390 (1932)

${ }^{107}$ INT. REv. CODE $\$ 3403(\mathrm{c})$.

${ }^{208}$ S. T. 648 , XII-I C. B. 384 (I932); S. T. 812, XIV-I C. B. 406 (I934).

${ }^{200}$ U. S. Treas. Reg. 46 (I940) $\$ 316.4$. See also S. T. 896 , r940-1 C. B. 252.

${ }^{200}$ Clawson \& Balls v. Harrison, supra note I7T. Accord: U. S. v. Armature Exchange, II6 F. (2d) 969 (C. C. A. 9 th, r94I).

${ }_{201}$ Moroley Bearing Service of Oakland, Ltd. v. U. S., 404 C. C. H. \$96rg (N. D. Cal. I940); J. Leslie Morris Co. v. U. S., 404 C. C. H. \$9608 (S. D. Cal. 1940).

${ }_{302}$ Revenue Act of 1932, $\$ 606(\mathrm{c})$, now INr. Rev. Code $\$ 3403(\mathrm{c})$. The Revenue Acts of 1978, $\$ 900(3), 1921, \$ 900(3)$, and $1924, \$ 600(3)$, contained no such provision.

${ }^{203}$ Cf. United States Light \& Heat Corp. v. U. S., 3 F. Supp. 86r (Ct. Cl. r933), cert. denied, 29r U. S. 67I (1934).

${ }^{204}$ Cf. Atwater Kent Mfg. Co. v. U. S., 62 Ct. Cl. 419 (Ig26).

${ }^{205} \mathrm{Cf}$. Advance Automobile Accessories Corp. v. U. S., 42 F. (2d) 595 (Ct. Cl. I930); Berg Brothers Mfg. Co. v. U. S., 67 Ct. Cl. I65 (r929); Atwater Kent Mfg. Co. v. U. S., stspra note 204 .

${ }^{300}$ Cf. American Chain Co. v. Hartford-Connecticut Fruit Co., 86 F. (2d) 105 (C. C. A. 2d, 1936).

${ }^{207}$ Held taxable as parts or accessories: Rochester Woven Belting Corp. v. U. S., 43 F. (2d) 264 (Ct.

Cl. r930) (transmission lining); Walker Mfg. Co, v، U, S., 65 Ct. Cl. 394 (1928) (jacks); Hinsdale Mfg. 
have thus been partly marked out, classification controversies will probably continue for some time, though in diminishing volume.

In sharp contrast to the situation involving parts and accessories, the taxes ${ }^{208}$ on motorcycles and on automobile and truck bodies and chassis occasion few difficulties. The term "manufacturer" does not include an automobile dealer who makes changes in an automobile at the request of the purchaser, if such changes do not affect the car's use. ${ }^{209}$ A hearse chassis ${ }^{210}$ is classified as a truck chassis, but fire trucks ${ }^{211}$ are not within the purview of this tax. It has also been ruled ${ }^{212}$ that a tank for a tank truck should be classified as a truck body. So-called "drive-away" sales have raised a question as to exportation. If an automobile or truck, delivered at the factory, is driven to Canada or Mexico or to a port for loading aboard ship and is not used for any other purpose on such trip, and if the time intervening between the delivery and arrival at the border or port of export is devoted to reaching that point, the vehicle will be considered as having been exported in due course and therefore as not taxable. ${ }^{213}$

Co. v. U. S., 43 F. (2d) 263 (Ct. Cl. 1930) (socket wrenches); Fairmont Tool \& Forging Co. v. U. S., 42 F. (2d) $59 x$ (Ct. Cl. r930) (tool kits); S. T. 643, XII-I C. B. 397 (r930) (auto radios); Bassick Mfg. Co. v. U. S., 44 F. (2d) 278 (Ct. Cl. I930) (grease guns); S. T. 739, XIII-1 C. B. 378 (1933) (floor mats); United States Gear Corp. v. U. S., 15 F. Supp. 66 (Ct. Cl. 1936) (differential, pinion, ring, and transmission gears); Brown Sheet Iron \& Steel Co. v. Willeuts, 45 F. (2d) 390 (C. C. A. 8th, 1930), aff'g 34 F. (2d) 969 (D. Minn. r929) (steel tanks for use on trucks); S. T. 44I, III-x C. B. 46r (r923) (hoists for trucks); E. Edeleman \& Co. v. U. S., 68 Ct. Cl. 168 (I929) (clocks and window antirattlers); Autoquip Mfg. Co. v. U. S., $68 \mathrm{Ct}$ Cl. 362 (1929) (hand pump and antirattlers); Weir v. McGrath, 52 F. (2d) 201 (S. D. Ohio r928) (carburetors); Imperial Brass Mfg. Co. v. U. S., 69 Ct. Cl. 20 (Ig29) (carburetor controls, primers, gasoline strainers, and air pumps); Eskstrom v. U. S., 2I F. Supp. 338 (Ct. Cl. 1937) (universal joints); S. T. 824, XIV-2 C. B. 368 (r934) (various articles cut from lengths or rolls of material and held in stock for sale); S. T. 573 , XT-2 C. B. 473 (I93 I) (battery cables, ignition cable sets, battery box hold-downs, and ignition wires cut into required lengths); Crawford Mfg. Co. v. U. S., 50 F. (2d) 280 (Ct. Cl. I93I) (top covers, back curtains, and seat and floor coverings); S. T. 605 , XI-2 C. B. 475. (193I) (windshield glass cut to size, wind wing brackets, rear vision mirrors, and headlight lenses cut from antiglare or beam refracting glass); G. C. M. II249, XI-2 C. B. 474 (193x) (parts for taxable parts and accessories); S. T. 760, XIII-2 C. B. 405 (1933) (metal base for solid tires); S. T. 606, XI-2 C. B. 476 (x93I) (taximeters); S. T. 834 , XV-1 C. B. 396 (1935) (baby auto seats, auto beds, and auto hammocks); S. T. 736, XIII-I C. B. 377 (I933) ("six wheel attachment"). Held nontaxable as parts or accessories: Weeks v. U. S., 42 F. (2d) 325 (Ct. Cl. 1930) (supercarburetor); W. M. Dutton \& Sons Co. v. U. S., 59 F. (2d) 839 (Ct. Cl. 1932) (hand pump); Frost Gear \& Forge Co. v. U. S., 52 F. (2d) ro23 (Ct. Cl. x93I) (pinion, ring, differential, and transmission gears); Cuno Engincering Corp. v. U. S., 43 F. (2d) 259 (Ct. Cl. r930) (electric cigar lighters, and combination lighters and ash receivers); Durkee-Atwood Co. v. Willcuts, 83 F. (2d) 995 (C. C. A. 8th, I936) (belts); Martin Rocking Fifth Wheel Co. v. U. S., 60 Ct. Cl. 466 (1925) (semitrailers); Eskstrom v. U. S., 21 F. Supp. 338 (Ct. Cl. 1937) (jumbo transmissions); S. T. 573, XI-2 C. B. 473 (I93I) (wrecking cranes for trucks, towing cradles, reboring machines, valve refacing machines, valve grinders, air compressors, paint sprayers, bushings, ball bearings, waterproof cement, paints, lacquers, and gasket cement); S. T. 605, XI-2 C. B. 475 (I93I) (headlight lenses cut from plain glass).

${ }_{208}$ INT. Rev. CODE $\$ 3403($ a), (b).

${ }^{200}$ J. W. Cox Motor Sales Co. v. Goodcell, 5 F. Supp. 630 (S. D. Cal. 1933).

${ }_{210}$ G. C. M. I2068, XII-2 C. B. 314 (I932).

${ }^{211}$ American-LaFrance Fire Engine Co. v. Riordan, 6 F. (2d) 964 (C. C. A. 2 d, I925); S. T. 626 , XII-x C. B. 387 (I933).

212 S. T. 468 , XI-2 C. B. 47 I (I931). ${ }^{213}$ S. T. 833 , XV-I C. B. 418 (1935). 


\section{Radio Sets}

The $\operatorname{tax}^{214}$ relating to radio receiving sets actually applies to the components enumerated in the statute ${ }^{215}$ rather than to the complete set itself. A result of this scheme of taxation is that, in particular instances, determination of liability by the taxpayer is beset with difficulties, and auditing of such determination by agents of the Bureau is unduly burdensome. Ordinarily, radio chassis and cabinet are made by different persons; the assembler of the complete set is the manufacturer of the chassis. Of course, if the assembler bills each taxable component separately, difficulties are avoided. But if he sells the set for a lump sum, he is compelled to allocate the total sales price of the taxable components between those which he manufactured himself and those which he purchased taxpaid, and to satisfy the Bureau that the allocation was proper. ${ }^{210}$ Unless he can do this, he is required to pay tax on all the taxable components. ${ }^{217}$ A solution to this problem would be to broaden this tax, as in the case of automobiles and parts and accessories, to cover complete sets in addition to the components now specified in the law. Although the adoption of this suggestion would reduce the difficulties involved in calculating the tax, it would substantially increase the tax burden, for the sales price of an assembled set, which includes cost of assembly, assembler's profits, and small parts not now taxable, is higher than the aggregate of the sales prices of the components.

Without any apparent justification the law draws a distinction between components for auto radios and components for other radios. A manufacturer may without payment of tax sell the former for use in the manufacturing of complete automobile sets taxable as accessories, ${ }^{218}$ whereas he may not sell components for other types of radio, without payment of tax, for use as material or as a component part of a radio chassis. ${ }^{219}$ Furthermore, components for auto radios are taxed at a lower rate than that applicable to components for other radios. ${ }^{20}$

\section{Household Refrigerators, Firearms and Ammunition, Matches}

Available information indicates that the Bureau has not encountered any particular difficulties in the administration of the statutory provisions imposing the taxes in respect of household refrigerators, ${ }^{221}$ firearms, ${ }^{222}$ shells, ${ }^{223}$ cartridges, ${ }^{224}$ and matches. ${ }^{225}$ Recently, however, an administrative ruling ${ }^{226}$ relating to shells and cartridges has been successfully assailed in a district court. ${ }^{\mathbf{2 2 7}}$ An exemption provision ${ }^{228}$ provides that no tax shall apply to the sale of an article for use by the vendee as material in the manufacture of, or as a component part of, an article subject to the manufacturers' excise taxes. The assailed ruling provides that where a manufac-

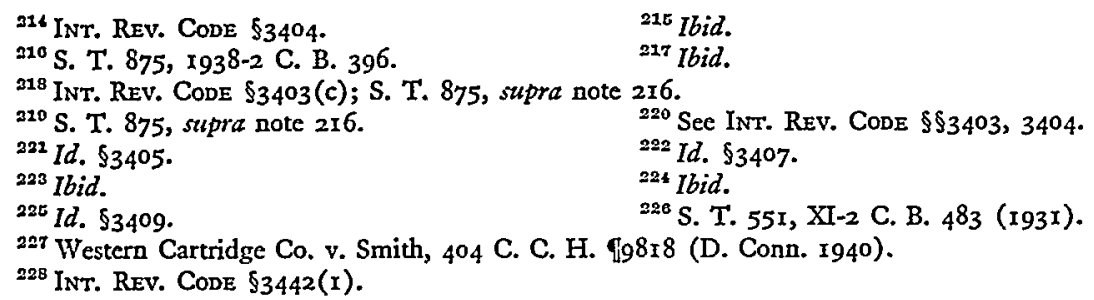


turer of shells and cartridges sells such articles to a firearms manufacturer for use in testing his firearms, the sale does not come within the exemption, the reasoning being that the ammunition cannot properly be said to have been used as material in the manufacture of, or as a component part of, the firearms so tested. The federal court, stating that the ruling was at variance with the plain language of the statute, held that the ammunition had been used as a material in the manufacture of firearms.

\section{Electrical Energy}

The tax ${ }^{229}$ in respect of electrical energy applies only to sales for domestic or commercial consumption and not to sales for resale. It thus discriminates against commercial as compared with industrial users. Moreover, since it does not apply to sales made by publicly-owned electric and power plants, ${ }^{230}$ or to states or their political subdivisions, ${ }^{231}$ it discriminates against private enterprise. Although the latter statement holds true as a general proposition, a recent amendment ${ }^{232}$ necessitates a qualification to the effect that this tax has no application to sales by rural electrification cooperatives or nomprofit corporations. This amendment was obviously made in furtherance of the Government's commendable rural electrification program. In view of the scope of the tax, classification problems as to use have been inevitable. A partial list of recent classification rulings is set forth in the margin. ${ }^{233}$ It may be supposed that those buying from power companies have attempted evasion by asserting that their use of energy is industrial. Probably this type of evasion is carried out successfully in numerous instances, for power companies are largely

${ }^{220} \mathrm{Id} . \S 34 \mathrm{rr}$.

230 lbid.

${ }^{231}$ G. C. M. 13754 , XIII-2 C. B. 408 (1933).

${ }^{232}$ Revenue Act of $1938, \$ 713(2)$, now INT. REv. Code $\$ 3411$ (c).

${ }^{233}$ Use held to be commercial or domestic: S. T. 909, 1940-2. C. B. 309 (churches, convents, charitable organizations, and nonprofit educational institutions, if use is actually domestic or commercial); S. T. 892, r939-2 C. B. 360 (repair shop, lighting hand laundry, tailor shop, physician's office); S. 'T. 674, XII-I C. B. 412 (I932) (cemetery garage); S. T. 652, XII-I C. B. 4II (I932), (chain store warchouses); S. T. 650 , XII-I C. B. 4XI (1932) (furnished by Government for specific charge for use by federal employees in living quarters); S. T. 637, XII-I C. B. 409 (1932) (dairy producing milk for retail purposes); S. T. 695 , XII-2 C. B. 324 (I932) (general farming operations); S. T. 6I5, XI-2 C. B. 504 (I93I) (cold storage warehouse); S. T. 576, XI-2 C. B. 502 (r93 $\mathrm{r}$ ) (radio broadcasting station operated for entertainment purposes); S. T. 562, XI-2 C. B. 50I (r93 I) (hospital operated for profit); S. T. 544, XI-2 C. B. 500 (193I) (church rectory); S. T. 527, XI-2 C. B. 499 (193I) (grain elevator where grain stored for resale or for account of producer); S. T. 525, XI-2 C. B. 499 (r93I) (branch house of meat packer used for refrigeration, storage, or distribution); S. T. 518, XT-2 C. B. 498 (193I) (branch office of dairy); S. T. 466 , XI-2 C. B. 497 (I93I) (motion picture theater); S. T. 464 , XI-2 C. B. 496 (I93I) (outdoor advertising); S. T. 463 , XI-2 C. B. 496 (I93I) (branch office of laundry); S. T. 569, XI-2 C. B. 50r (r93I) (scavenger company operating under contract with city). Use held not to be commercial or domestic: S. T. 892 , I939-2 C. B. 360 (clothing manufacturer; printing establishment; maker of Christmas cards); S. T. 64 I, XII-I C. B. 4 IO (I932) (closed industrial plants); S. T. 695, XII-2 C. B. 324 (1932) (irrigation purposes on farm); S. T. 483 , XI-2 C. B. 497 (I93I) (railroad dock facilities for loading and unloading ships); S. T. 570, XI-2 C. B. 502 (I93I) (nonprofit agricultural fair); S. T. 535, XI-2 C. B. 500 (193I) (nonprofit institution for promotion of knowledge and service in industry); S. T. 545, XI-2 C. B. 500 (I93 I) (bus company for operations as common carrier); S. T. 576, XI-2 C. B. 502 (I93I) (radio broadcasting station owned and operated by educational or religious institution for broadcasting educational or religious programs; regular activities of nonprofit schools, colleges, and universities); S. T. 562, XI-2 C. B. 50 I (I93I) (nonprofit hospital); S. T. 527, XI-2 C. B. 499 (I93I) (grain elevator where grain cleaned, ground, and bleached); S. T. 525, XI-2 C. B. 499 (I93I) (branch house of meat packer used for processing meat); S. T. 5 I 8, XI-2 C. B. 498 (I93I) (pasteurization and bottling mills, and manufacture of butter, buttermilk, and cottage cheese); S. T. 463, XI-2 C. B. 496 (193I) (laundry plant). 
dependent upon their customers for information as to use and the task of investigating each case is administratively infeasible. It is plain that the discriminatory effects of this tax could be eliminated only by extending its coverage to all sales regardless of the type of use and by restricting exemptions to sales to governmental bodies.

\section{Gasoline}

The basis for the gasoline tax is quantitative. ${ }^{234}$ As gasoline prices fluctuate almost daily, because of price wars, unfair competition by so-called bootleggers dealing in contraband gasoline, and similar practices, the quantity basis for tax measurement is more equitable to the members of this industry than would be a price measure. Moreover, this basis greatly simplifies the administration of the statutory provisions relating to this tax; in turn, those provisions do not give rise to serious classification or other administrative difficulties. Furthermore, tax evasion appears to be a minor problem in this field. Industry members, well organized into associations for policing the industry against unfair competitive practices, find it definitely to their interest promptly to report instances of tax evasion to the Government.

\section{Lubricating Oil}

A quantity basis ${ }^{235}$ for measuring liability is also provided for the $\operatorname{tax}^{236}$ relating to lubricating oil. The reasons for the adoption of such a basis are substantially the same as in the case of the gasoline tax. Also, in view of the fact that the major members of this industry are well organized to police the industry, tax evasion is not a serious problem, though the Bureau has found instances in which either oil later used for lubrication has been sold tax free under certificates ostensibly for nonlubrication purposes or lubricating oil has been sold as nontaxable grease.

As the statutory provisions relating to this tax do not define the terms "manufacturer," "producer," and "lubricating oils," classification problems have arisen in the course of their administration. A person who merely blends or mixes two or more different grades of lubricating oils is not a manufacturer or producer, ${ }^{237}$ but if he employs a process of compounding or other manipulation involving substantially more than the mere mixing of taxable oils, or if he mixes taxable oils with other substances, he is classified as a manufacturer or producer. ${ }^{238}$ Similarly, a person who produces reclaimed lubricating oils is a manufacturer or producer within the statute. ${ }^{239}$ When a person produces lubricating oil in nonfluid form, he may treat eight pounds of such product as the equivalent of one gallon for the purpose of measuring his liability. ${ }^{240}$ An oil having both lubricating and nonlubricating uses may be sold tax free, if the manufacturer obtains an exemption certificate ${ }^{241}$ and if the oil is put in a channel of consumption or distribution directed to such other

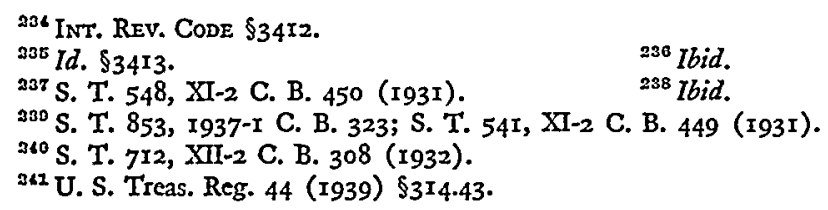


use. ${ }^{242}$ The types of oils which the Bureau regards as taxable under this tax are indicated by the classification rulings listed in the margin. ${ }^{243}$

Questions have also arisen as to whether lubricating oil obtained by a vendee is nontaxable because used as material in the manufacture of, or as a component part of, an article subject to a manufacturers' excise tax. ${ }^{244}$ Lubricating oil mixed with gasoline in the ratio of one part oil to ninety-nine parts gasoline is regarded as being a component part of the gasoline and may therefore be purchased tax free for that purpose. ${ }^{245}$ On the other hand, an automobile manufacturer may not purchase tax free, oil for the crank cases of automobiles of his manufacture, ${ }^{240}$ nor may a manufacturer of a taxable product avoid tax on oil which will be consumed in the process of manufacturing that product without becoming a component material of the finished product. ${ }^{247}$

\section{Measurement of Price}

The purpose of the general statutory provision ${ }^{248}$ with respect to the determination of price is to require the inclusion in the selling price of certain charges so closely connected with the cost of manufacture or production as to constitute part of the charge and to authorize the exclusion of other charges which, though they increase the cost to the customer, form no integral part of the sale price. ${ }^{249}$ The phrase "in condition packed ready for shipment," clusion in the price basis of charges incident to placing the article in such condition, has reference to an article packed ready for delivery to a customer upon a bona fide sale. ${ }^{251}$ The charges which may be excluded from the price basis under this general provision all relate to events occurring after the articles leave the point where delivery commences-the factory or warehouse, as the case may be. ${ }^{252}$ Freight charges incurred in moving articles from factory to warehouse before sale or from one warehouse to another before sale are accordingly included in the price. ${ }^{253}$ But freight charges incurred after sale in shipping articles to customers may be excluded, and in such a case it is immaterial whether the sale was f.o.b. factory, or the manufacturer prepaid such charges, or the sale was made with "freight deductible" or "freight allowed."264 The expenses and commissions of a demonstrator selling articles subject to this general provision are regarded as part of the selling price. ${ }^{255}$ If a manufacturer includes so-called "free" articles in a shipment billed at the regular price, the "free"

${ }^{242}$ S. T. $828, X V-$ I C. B. 380 (I935).

${ }^{243}$ Taxable: S. T. 505, XI-2 C. B. 448 (1931) (for cutting and machinery operations on metals). Nontaxable: S. T. 905 , 1940-2 C. B. 305 (agricultural spray oil, air conditioning oil, battery oil, paint oil, putty oil, rust preventive oil, if sold by manufacturer direct to consumer); S. T. 844, XV-2 C. B. 330 (1935) (highly refined special white oil); S. T. 839, XV-r C. B. 379 (1935) (crude neatsfoot oil and transformer oil); S. T. 803, XIV-I C. B. ${ }_{405}$ (1934) (petrolatum); S. T. 540 , XI-2 C. B. 448 (193X) (fatty oils of vegetable, animal, fish, or marine origin).

${ }^{244}$ INT. REV. CODE $\$ 3442(\mathrm{r})$.

${ }^{246}$ S. T. $57 \mathrm{I}, \mathrm{XI}-2$ C. B. $45 \mathrm{I}$ (193I).

${ }^{248}$ INT. REV. CODE \$344I(a).

${ }^{250}$ INT. REV. CODE \$344I(a).

${ }^{252} \mathrm{Ibid}$.

${ }^{254}$ S. T. 5I3, XI-2 C. B. 5 II (I93I).

${ }^{245}$ G. C. M. $1566 \mathrm{I}, \mathrm{XIV}-2$ C. B. 370 (1934).

${ }^{247}$ S. T. $460, \mathrm{XI}-2$ C. B. 514 (193I).

${ }^{240}$ G. C. M. 21114 , 1939-I C. B. 35 r.

262 G. C. M. 2 III4, supra note 249.

${ }^{265}$ Ibid.

${ }^{265}$ S. T. 678 , XII-I C. B. 415 (1932). 
articles are not regarded by the Bureau as a gift; they simply reduce the price of the entire shipment. ${ }^{256}$ Cash discounts and trade discounts are subject to different rules. In the case of a cash discount, the tax is computed upon the total price, but the manufacturer may, in the month when the discount becomes effective, recompute the tax on the net price and take credit for the difference on his return. ${ }^{257}$ Of course, if the discount becomes effective in the month of sale, he may recompute his tax on the net price and pay only the amount so computed. ${ }^{258}$ Where a trade discount is granted unconditionally at the time of sale, such discount may be deducted from the price and the tax computed on that basis. ${ }^{259}$

\section{Exemption of Subsequent Sales}

In conformity with a dictum in the Indian Motorcycle case ${ }^{280}$ to the effect that a manufacturers' excise tax is laid only on the first or initial sale, the Bureau has ruled $^{261}$ that payment of the tax with respect to any particular article establishes complete immunity from tax for subsequent resales or uses. Thus, if a manufacturer reacquires a taxpaid article, as a trade-in or otherwise, a subsequent sale by him of that article is not taxable. ${ }^{202}$ Questions have also arisen as to taxability of replacements. If a defective article is replaced by the manufacture under a guaranty contract and the manufacturer receives no consideration other than the defective article, the transaction is not a sale and is consequently not taxable. ${ }^{263}$ But where an article is sold under a warranty as to quality or service and the manufacturer is required to replace it with a similar article for a payment less than the original price, the transaction is a sale. ${ }^{264}$ In such a case, if the tax base is the price, the tax is computed on the second payment; if the base is quantitative, the tax is computed upon that proportion of the total weight of the second article which the reduced payment bears to the regular sales price. ${ }^{265}$

\section{Credits and Refunds}

No credit or refund of an overpayment of any manufacturers' excise tax may be made unless the taxpayer establishes in accordance with regulations prescribed by the Commissioner that either he has not included the tax in the price of the article or has repaid the amount of the tax to the ultimate purchaser, or unless he files with the Commissioner the consent of such purchaser to the allowance of credit or refund. ${ }^{206}$ The validity of corresponding limitations in former revenue acts has been upheld by the Supreme Court. ${ }^{267}$ The earlier limitations provided that the exclusion of the tax from the price or the repayment thereof to the ultimate purchaser should be established "to the satisfaction of the Commissioner." Such phrase, the Court pointed out, did not give the Commissioner absolute authority as to credits

\footnotetext{
${ }^{260}$ S. T. 484, XI-2 C. B. 508 (x93I).

${ }^{257}$ S. T. 616, XI-2 C. B. 5 II2 (193I).

${ }^{208}$ Ibid.

${ }^{259}$ S. T. 628 , XII-I C. B. 415 (I932).

${ }^{260}$ Indian Motorcycle Co. v. U. S., supra note $\mathbf{1 6 2 .}$

${ }^{203} \mathrm{Ibid}$.

${ }^{206}$ S. T. 644 , XII-I C. B. 38I (1932).

${ }^{202}$ S. T. $867, x 937-2$ C. B. 505.

${ }^{203}$ S. T. $613, \mathrm{XI}-2$ C. B. 454 (x93I).

${ }^{280}$ INT. REV. CODE $\$ 3443$ (d).

${ }^{205} 1$ lbid.

${ }^{207}$ U. S. v. Jefferson Electric Mfg. Co., 29I U. S. 386 (1934).
} 
and refunds; it was simply admonitive and meant proof which convinces in the sense of inducing belief. ${ }^{208}$ Clearly, then, the present requirement that the facts must be established in accordance with the Commissioner's regulations is valid. If, in the case of any tax measured by price, the customer's bill does not indicate whether the tax was included in the total price, it will be presumed that it was so included, unless the presumption is overcome by evidence satisfactory to the Commissioner. ${ }^{200}$ A person who purchases a taxpaid article for consumption or for use in the manufacture of other articles and not for resale, is an ultimate purchaser within the statutory provision under consideration. ${ }^{270}$

\section{Sales for Use of the United States}

The statutory provision ${ }^{271}$ exempting sales of articles for the exclusive use of the United States embraces sales to corporations wholly owned by the United States, ${ }^{272}$ but not corporations which are only partly owned by the Government.273 This exemption also includes sales of articles for use on vessels owned by the United States which are under the control of the Department of Commerce and operated by the United States Shipping Board Merchant Fleet Corporation pursunnt to a managing agency agreement. ${ }^{274}$ Exemption is also granted to sales of articles for the exclusive use of any state or political subdivision thereof. ${ }^{275}$ Cooperative and self-help associations organized for mutual aid and assistance and receiving federal funds for the accomplishment of their purpose are simply organizations of individuals rather than governmental bodies within this exemption. . $^{27}$ The meaning of the terms used in such exemption are for determination by the Government and may not be restricted by the views of a state. ${ }^{277}$ Thus, an irrigation district will be regarded as a political subdivision within this exemption, despite a state court decision to the contrary. ${ }^{278}$ Another exemption ${ }^{279}$ is granted to sales of articles for use on specified classes of vessels. Included in this group are vessels of war of the United States, although vessels of the Coast Guard may not, during peace time, be so classified.280

\section{Articles for Export}

The application to specific instances of the constitutional inhibition ${ }^{281}$ against taxation of articles exported from any state has in the past occasioned some difficulties, though these have been largely, if not entirely, cleared away by the Spalding decision. ${ }^{282}$ In that case, the articles were sold by the manufacturer to a commission merchant for exportation to a foreign consignee, the sale being consummated by the delivery of the articles, addressed to the consignee, to the exporting carrier. The

${ }^{208}$ Ibid.

${ }^{200}$ S. T. 785, XIII-2 C. B. 4 I3 (1933). $\quad{ }^{270}$ S. T. 690, XII-2 C. B. 341 (1932).

${ }^{271}$ INT. REv. CODE $\S_{3442(3)}$. No such statutory exemption is provided for the analogous sugar tax, and exemption is denied by Bureau ruling. P. T. $35,1937-2$ C. B. 530 .

${ }^{272}$ S. T. 842, XV-2 C. B. 346 (1935).

274 S. T. 847, XV-2 C. B. 347 (1935). 275 INT. REv. CODE $\$ 3442(3)$.

${ }^{278}$ S. T. 796, XIV-I C. B. 4 II (x934).

278 Ibid.

${ }^{280}$ S. T. 724, XIII-I C. B. 390 (1933).

${ }^{270}$ INT. REv. CODE $\$ 3451$.

282 Spalding \& Bros, v. Edwards, 262 U. S. 66 (1923).

${ }^{31}$ U. S. Const. Art. $1, \S 9$, cl. 5. 
Court held that as the sale was a step in exportation it was not taxable; the possibility that the commission merchant might have changed his mind and diverted the goods into domestic channels was deemed to be immaterial. Thus, if the sale and delivery by the manufacturer actually start the article to its foreign destination, either by the immediate carrier or through connecting carriers, the sale is exempt. ${ }^{283}$ It is immaterial that further acts remain to be done before the goods are loaded on the vessel, so long as such acts are only the regular steps to the contemplated result of exportation. ${ }^{284}$ Nor is it necessary that the shipment be upon through bills of lading. ${ }^{285}$

\section{Intercompany Sales}

Although manufacturers have gone to great lengths to avoid tax through the medium of varying forms of intercompany sales, the Bureau and the courts have made short shrift of most of these subterfuges. The transfer of large inventories by the manufacturer to a sales subsidiary shortly before the adoption of these taxes did not have the desired effect of insulating the manufacturer from taxation with respect to sales made by the subsidiary after the effective date of the tax. ${ }^{286}$ The entire scheme was a "colorable sham," an arrangement to avoid tax. ${ }^{287}$ The sales subsidiary was simply the instrumentality or agency of the manufacturer. ${ }^{288}$ Moreover, Congress clearly foresaw that such stratagems might be resorted to after the enactment of the law and guarded against them by including therein a provision that if an article is sold (otherwise than through an arm's length transaction) at less than the fair market price, the tax shall be computed on the price for which like articles are sold, in the ordinary course of trade, by manufacturers or producers, as determined by the Commissioner. ${ }^{289}$ This provision hàs been invoked in the case of sales between (I) a manufacturing company and a sales subsidiary, ${ }^{290}$ (2) a manufacturing company and an affiliated sales company, ${ }^{201}$ and (3) a manufacturing plant and a sales plant owned by the same company. ${ }^{202}$

\section{Communication Facilities}

The taxes ${ }^{293}$ in respect of telephone conversations, telegraph, cable, and radio messages, and leased wire or talking circuits, have apparently occasioned little diffculty. In any instance the tax applies only to a service for which a charge, in money or money's worth, is made ${ }^{294}$ and, in the case of telephone conversations, only if the

${ }^{283}$ T. D. 3495 , II-2 C. B. 293 (I 922 ).

284 Ibid. $3495,11-2$ C. B. 293 (1922). ${ }^{285}$ Ibid.

${ }^{280}$ Continental Oil Co. v. Jones, II3 F. (2d) 557 (C. C. A. Ioth, 1940); E. Albrecht \& Son v. Landy, 27 F. Supp. 65 (D. Minn. I939); G. C. M. 14526, XIV-I C. B. 417 (1934).

287 G. C. M. I4526, supra note 286 .

${ }^{288}$ E. Albrecht \& Son v. Landy, G. C. M. I4526, both supra note 286.

280 INT. REv. CoDe $\$ 344$ I (b) (3).

200 Campana Corp. v. Harrison, II 4 F. (2d) 400 (C. C. A. 7th, I940); Bourjois, Inc. v. McGowan, 12 F. Supp. 787 (W. D. N. Y. 1935), aff'd, 85 F. (2d) 5 10 (C. C. A. 2d, 1936), cert. denied, 300 U. S. 682 (1937); S. T. 673 , XII-I C. B. 400 (1933).

${ }_{201}$ Inecto, Inc. v. Higgins, 21 F. Supp. 418 (S. D. N. Y. I937); S. T. 617, XI-2 C. B. 513 (I931).

${ }^{203}$ S. T. 487, XI-2 C. B. 455 (I93). ${ }^{293}$ INT. REv. CODE $\$ 3465$.

${ }^{204}$ Ibid. See also U. S. Treas. Reg. 42 (I932) art. 4. 
charge is above a stated minimum. ${ }^{295}$ It is paid to the service company by the person using the communication facility, and by such company is paid over to the Government. $^{206}$ Where a telegraph message is phoned over the facilities of a telephone company, the latter acting as agent for the telegraph company, the responsibility for collecting the tax rests with the principal. ${ }^{207}$ Even though special statutory provision is not made for the determination of the tax base in cases in which messages are transmitted for the performance of services, as under a contract between a telegraph company and a railroad company for the exchange of services, the Bureau's posi$\operatorname{tion}^{288}$ is that in such cases each message or conversation must be considered as a separate transmission and the tax computed upon the basis of the regular established charge for the transmission of single messages of the same character. This method of tax determination under similar earlier laws was fully sustained by the courts. ${ }^{200}$

The tax base, in the case of telephone conversations, has been broadened ${ }^{300}$ to cover a charge not strictly made for the use of the facilities, the charge exacted for messenger-paging service provided by the company for the convenience of its patrons. The tax ${ }^{301}$ relating to leased wires and talking circuits would seem to apply without any limitations, other than the statutory exception as to such facilities when used by specified companies in the conduct of their business as such. Nevertheless, if the terminals of a leased wire service are all located within an area served by a local exchange which does not charge tolls upon messages transmitted between points within such area, it has been ruled ${ }^{302}$ that messages over the leased wire are not taxable. The exemption ${ }^{303}$ as to facilities utilized in the collection of news for the public press or in the dissemination of news through the public press does not extend to messages by newspapers covering information or items for publication in periodicals published for information on particular subjects or of interest only to particular groups; such messages are not news within the meaning of the statute. ${ }^{304}$ Administrative messages of newspapers or press associations ${ }^{305}$ are similarly not embraced by the exemption. ${ }^{306}$

\section{Bituminous Coat}

The statute ${ }^{307}$ imposes two taxes with respect to sales and other disposals of bituminous coal by producers: (I) a tax ${ }^{308}$ of one cent per ton, which applies to all producers; and (2) a tax ${ }^{309}$ in an amount equal to $19 \frac{1}{2}$ per cent of the selling price or fair-market value of the coal, applicable to nonmembers of the Bituminous

${ }^{205}$ INT. REV. CODE $\$ 3465$ (a)(I).

${ }^{200} 1 d . \$ 3467$.

${ }^{207}$ S. T. 556, XI-2 C. B. 521 (193I).

${ }^{208}$ U. S. Treas. Reg. 42 (1932) art. 6.

290 Hellmich v. Missouri Pacific R. R., 273 U. S. 242 (I927); Erie R. R. v. U. S., 54 F. (2d) 173 (Ct. Cl. I93I), cert. denied, 286 U. S. 553 (1932); Delaware, L. \& W. R. R. v. Bowers, 28 F. (2d) 33 (S. D. N. Y. I926).

${ }^{300}$ S. T. 667 , XII-I C. B. 42 I (1932).

${ }^{302}$ S. T. $893,1939-2$ C. B. 364 .

${ }^{304}$ S. T. 646, XII-I C. B. 422 (1932).

${ }^{301}$ INT. REv. CODE $\$ 3465$ (b).

${ }^{303}$ INT. REv. CODE $\$ 3466$.

${ }^{300}$ The tax on the transportation of oil by pipe line is in effect a tax on the use of transportation facilities. Space limitations preclude consideration of the interpretive problems arising under it.

${ }^{307}$ INT. REv. CODE C. 33 .

${ }^{308}$ Id. $\$ 3520$ (a)(I).

${ }^{300}$ Id. $\$ 3520(\mathrm{~b})(\mathrm{r})$. 
Coal Code. The tax provisions under consideration were originally enacted as part of the Bituminous Coal Act of $1937,{ }^{310}$ the objective of which was the stabilization of the soft coal industry through price-fixing and the elimination of unfair competition. $^{311}$ The tax applicable to nonmembers of the Code is clearly not designed merely for revenue purposes. As a matter of fact, such tax, in purpose and effect, is primarily a sanction to enforce the regulatory provisions of the act. Nevertheless, it is constitutional..$^{312}$ Congress may utilize the power of taxation as a sanction in aid of the exercise of another power granted to it by the Constitution. The validity of the tonnage tax has also been sustained. ${ }^{313}$

\section{Conclusions}

The most outstanding characteristics of the federal consumption excises are their great adaptability to revenue and nonrevenue purposes and the effectiveness with which they may be used in both spheres. Of the taxes considered in this paper, three groups, ${ }^{314}$ taken together, produced over $\$ 1,600,000,000$ in $19400^{315}$ On the other hand, consumption excises have been utilized, often with drastic effectiveness, to protect the public health or safety, to protect the public against fraudulent practices, to protect certain businesses or industries against others, or to compel compliance with Congressionally determined standards. Generally speaking, such nonrevenue purposes are accomplished by one of three methods: (I) destructive taxation; (2) regulatory provisions linked with tax-imposing provisions; or (3) utilization of the taxing power as a sanction. The advantage of the first method is that it is apparently subject to no special ${ }^{316}$ limitations. In any event, there is no case in which an excise tax has been struck down solely because it was destructive. The disadvantage arises from its very destructiveness. It can be used only to destroy. The second and third methods, on the contrary, can be adjusted with utmost nicety to meet an infinite variety of situations. In the case of the second method, the special limitation would seem to be that the statute must be dressed in the language of a revenue measure and the regulatory provisions must bear some reasonable relation to the exercise of the taxing power; that is, such provisions must show on their face that they tend to protect the revenue or to facilitate its collection. ${ }^{317}$ The special limitation applicable to the third method is the validity of the Congressionally determined standards. If the latter represent the proper exercise of a Congressional power, the tax is valid as an aid to the exercise of that other power. ${ }^{318}$

\footnotetext{
${ }^{320} 50$ StAT. 75 (I937), 15 U. S. C. A. $\$ 830$ (1939).

311 See Sunshine Anthracite Coal Co. v. Adkins, 3I0 U. S. 38 I (I940).

${ }^{310}$ Ibid.

${ }^{318}$ Winslow Coal Corp. v. Smith, 404 C. C. H. $\$ 945^{8}$ (S. D. Ind. 1940).

314 'Tobacco, liquor, and manufacturers' excise taxes.

${ }^{316}$ Rep. CoM'r INT. Rev. (I940) 2, 23, 25.

310 "The word "special" as used in this paragraph has reference to limitations other than the general constitutional limitations that taxes must be uniform and that no tax may be laid on articles exported.

${ }^{317}$ See U. S. v. Doremus, supra note 140 .

${ }^{318}$ See Sunshine Anthracite Coal Co. v. Adkins, supra note 311.
} 